\title{
DE LA VERGÜENZA Y LA CULPA AL MIEDO. CADENA DE EMOCIONES TRAS UN SUICIDIO
}

\author{
FROM SHAME AND GUILT TO FEAR. \\ CHAin OF EMOTIONS AFTER A SUICIDE
}

\author{
Laura Hernández Ruiz* \\ doi: https://doi.org/10.31644/ED.V9.N1.2022.A11
}

\begin{abstract}
Resumen: Las emociones revelan las ideas, percepciones y creencias que los individuos construyen sobre aquellos temas que tocan sus vidas de manera sensible. La experiencia de un acontecimiento como el suicidio suscita, reproduce y condiciona emociones entre los deudos y algunos miembros de su comunidad, lo que origina cambios en la dinámica social. En este artículo, más que tratar de comprender las causas que llevan a alguien a suicidarse y los sentimientos que los pueden orillar a dicho acto, nos centramos en las emociones que experimentan los que se quedan. A partir de la revisión de entrevistas realizadas entre 2006 y 2007 a tres mujeres de Yucatán tras el suicidio de un familiar se identifican las situaciones que convocan diferentes emociones y se analiza cómo estas se entretejen, de manera similar a una cadena que acompaña el duelo y que devela los condicionantes sociales — diferencia y subordinación- en la vida cotidiana de los actores. A su vez, se reconocen los cambios que se originan en la dinámica de la comunidad.
\end{abstract}

Palabras clave: emociones, suicidio, familia, duelo, dinámica social.

Abstract: Emotions reveal the ideas, perceptions and beliefs that individuals build on those issues that touch their lives in a sensitive way. The experience of an event such as suicide raises, reproduces and conciliates emotions among the relatives and some members of their community, which in turn causes changes in social dynamics. In this article, rather than trying to understand the causes that lead someone to commit suicide and the feelings that can lead to this act, we focus on the emotions experienced by those who remain. This is done from the review of the interviews conducted with three women from Yucatán, between 2006 and 2007, after the suicide of a relative. From their speeches, the situations that summon different emotions are identified and

\footnotetext{
* Dra. en Antropología, área de Lingüística, profesora Centro Peninsular en Humanidades y Ciencias Sociales, Universidad Autónoma del Estado de México, México. ORCiD: https://orcid.org/0000-0002-5687-284X. Correo-e: laheru@hotmail.com; laheru@unam.mx.
}

Fecha de recepción: 24/03/2020. Fecha de aceptación: 16/08/2021. Fecha de publicación: 31/01/2022.

\section{(cc) BY-NC-ND}

EntreDiversidades. Revista de Ciencias Sociales y Humanidades, Vol. 9, Núm. 1 (18), enero-junio 2022. Páginas: $272-297$ ISSN-e: 2007-7610. https://doi.org/10.31644/ED.V9.N1.2022.A11 
an analysis is made of how they interweave, as a chain that accompanies the mourning, which reveals the social conditions — difference and subordination — in the actors' daily life. Likewise, the changes that originate in the dynamics of the community are recognized.

Keywords: emotions, suicide, family, grief, social dynamics.

\section{Introducción}

El ser humano vive en sociedad, esto conlleva el mantener vínculos seguros como la conservación de una adecuada distancia social, el conocimiento y aceptación del otro (Bericat, 2000: 166). Sin embargo, las relaciones cotidianas muestran que hay factores como las emociones que emergen y pueden apoderarse de las situaciones sociales. Por ello, es importante identificar no solo las emociones, sino también las circunstancias que las convocan.

Las emociones, como constructo, son difíciles de definir. Aunque se han convertido en un foco de interés en las ciencias sociales, ${ }^{1}$ no existe consenso en su definición, de ahí que establecer sus fronteras y modalidades es una tarea compleja. De hecho, hoy su origen y estructura interna continúan siendo objeto de debate e investigación, así como sucede con el establecimiento de las diferencias entre estados afectivos. Esto debido a que involucran procesos fisiológicos, cognitivos, conductuales y sociales.

En el estudio de las emociones se pueden ubicar diferentes enfoques. ${ }^{2}$ Cada uno de ellos las concibe de manera distinta, se centra en problemáticas específicas y utiliza diferentes herramientas para su análisis. Así, se encuentra la perspectiva darwiniana, la jamesiana, la del racionalismo, del conductismo y del constructivismo, entre otras tantas, y más recientemente la antropología y la sociología de las emociones. Todas cuentan con sus propios preceptos sobre la naturaleza de la emoción y cómo llevar a cabo investigaciones en este campo. Sin embargo, existen varias áreas de traslape en las mismas.

La perspectiva que adoptamos en este texto parte de un enfoque sociológico que toma en cuenta la construcción social de las emociones (Lutz, 1988: 247; Armon-Jones, 1985: 1-22), su comprensión y su explicación en contextos sociales (Durkheim, 2012 [1897]: 28-36; Ortony, Clore y Collins, 1988: 161), su regulación y expresión (Hochschild, 1975: 553), el papel que desempeńan en la acción colectiva (Flam, 1990: 2; Barbalet, 1998: 96), así como en la construcción o ruptura de vínculos sociales (Turner, 2007: 8-9). De esta manera, se identifican las emociones que suscita un suicidio entre los deudos y algunos miembros de la comunidad de este estudio. A partir de dichas experiencias emocionales se pueden evidenciar los condicionantes sociales que ayudan a entender lo que acontece en la vida cotidiana de los actores sociales, así como lo que los lleva a actuar de cierta manera. Es de precisar que el tono descriptivo del documento, en particular durante los testimonios de las mujeres tras el suicidio de algún familiar cercano, es necesario para

\footnotetext{
1 "El giro afectivo puede ser entonces presentado como un proyecto destinado a indagar en formas alternativas de aproximarse a la dimensión afectiva, pasional o emocional —y discutir las diferencias que pueda haber entre estas tres denominaciones - a partir de su rol en el ámbito público” (Macón, 2014: 168).

${ }^{2}$ Para un recuento detallado de estas diferentes perspectivas consúltese Enciso y Lara, 2014.
}

EntreDiversidades. Revista de Ciencias Sociales y Humanidades, Vol. 9, Núm. 1 (18), enero-junio 2022. Páginas: 272-297 ISSN-e: 2007-7610. https://doi.org/10.31644/ED.V9.N1.2022.A11 
el análisis de las experiencias emocionales de las entrevistadas, ya que permite identificar parte de las creencias y saberes de las personas ante tal fenómeno en la región, así como la dinámica social de la comunidad. Se debe tomar en consideración lo que señala Fernández (2011: 3): “atrapar la energía emocional y traducirla en palabras es prácticamente imposible”, por lo que haremos lo que la autora sugiere, "zambullirnos en la marea emocional y nadar en su universo que es por definición: inconmensurable, complejo, diverso, subjetivo, misterioso y apasionante” (2011:3).

El texto está dividido en cuatro secciones. En la primera, "Sobre las emociones", se abordan algunos planteamientos esenciales para entender la naturaleza de las emociones y se enfatiza la importancia de su estudio. La segunda corresponde a las "Consideraciones metodológicas", en ella se describe la población entrevistada, así como el acercamiento analítico para captar e inferir las emociones, su secuencia y la dinámica social, a partir de las entrevistas realizadas a los parientes de los suicidas. En la tercera, "Itinerarios emocionales ante un suicidio", se identifican las emociones que surgen en los relatos de tres mujeres de Yucatán, familiares de suicidas. En estos se muestra cómo vivieron sus experiencias emocionales, incluyendo su atribución causal, la afectación y funciones sociales que emanaron de cada estado emocional, así como las estrategias utilizadas para encararlo. En la cuarta, "Consideraciones finales", se revisa el surgimiento de emociones entre los diferentes actores, se comparten algunas de las creencias, saberes y dinámicas sociales de la comunidad, así como el punto de convergencia para restablecer la dinámica de la comunidad.

\section{Sobre las emociones}

Como explican Gutiérrez, Arbesú y Piña (2014: 28) "los análisis de lo que se denomina comúnmente emociones (miedo, cólera, vergüenza, orgullo, odio, amor, piedad, indignación, alegría, tristeza, etcétera) muestran que estas no pueden ser reducidas a sensaciones puras, reacciones simples o pulsiones". Actualmente, las emociones se reconocen como factores fundamentales, no solo en el estudio de lo individual, sino también en relación con los comportamientos colectivos. Lo anterior se complementa con lo que señalan Gutiérrez y Reyna (2015: 126): "las emociones están presentes en nuestras vidas, prácticamente en todas las actividades que desempeńamos; estas constituyen fuerzas poderosas que influyen en la conducta y en la experiencia subjetiva del ser humano". De hecho, se ha sugerido que un coeficiente emocional alto puede ayudar más a resolver los conflictos de la vida diaria que un coeficiente intelectual elevado. De ahí que su estudio sea indispensable para identificar "las formas en que los actores en la vida cotidiana se posicionan frente a las diversas proposiciones y discursos que configuran los sistemas culturales" (Rodríguez, 2008: 146).

Así, como seńala Bericat (2001: 70), es necesario tomar en cuenta que "ninguna teoría que pretenda explicar o comprender un fenómeno social puede llegar a ser perfectamente inteligible si no se consideran los contenidos emocionales implicados en el fenómeno bajo estudio". Para el caso particular de este texto es preciso considerar también lo que Durkheim (2012 [1897]: 9) aclara: "Dado que el suicidio, tal como aparece hoy, es una de las formas en que se traduce la afección colectiva que todos padecemos, [su estudio] nos puede ayudar a comprenderla”. De igual

EntreDiversidades. Revista de Ciencias Sociales y Humanidades, Vol. 9, Núm. 1 (18), enero-junio 2022. Páginas: 272-297 ISSN-e: 2007-7610. https://doi.org/10.31644/ED.V9.N1.2022.A11 
modo, como argumenta Payá (2012: 69) el ser humano "se encuentra atravesado por el lenguaje, las tradiciones y prácticas sociales de su tiempo. Nadie se debe únicamente a sí mismo. Todo gesto va dirigido siempre a otro. La muerte, como la escritura, se brinda a alguien más. El acto suicida está inmerso en el campo grupal, aunque sea el cuerpo individual el que actúa”. De ahí que un suicidio genera en los familiares, amigos y vecinos un cúmulo de emociones que conviene revisar.

Asimismo, de acuerdo con Hochschild (1975: 288, citado en Bericat, 2000: 160) la sociología de las emociones ha aportado planteamientos esenciales para entender que "las emociones están cargadas de significados, de sentidos anclados en unos específicos contextos socio-históricos, entre cuyas dimensiones merece la pena señalar la dimensión normativa, la dimensión expresiva y la dimensión política”. La primera permite al sujeto dilucidar lo que es correcto y lo que no es socialmente aceptado, lo que puede generar una fuente de conflictos latente entre el individuo y los juicios u opiniones de los demás, como se observa en los casos aquí presentados. La dimensión política se refiere al objetivo de los sentimientos entre quienes tienen autoridad y los que no la tienen; así, la distribución diferenciada del poder determina el impacto de las emociones en varios de los casos aquí citados. Aunado a ellas, la dimensión expresiva trata de la relación entre la emoción expresada y la comprendida por los demás. Por otra parte, "Kemper entiende el concepto de estructura social como distribución desigualitaria de posiciones en los dos ejes de poder y estatus, esto es, considera ambas dimensiones en el sentido escalar, por lo que los individuos cuentan siempre con cantidades relativas de mayor o menor poder y estatus" (Kemper, 1978, citado en Bericat, 2000: 153). De este modo, cada actor está en una constante evaluación o ajuste de su conducta con respecto al poder y estatus de los demás; de ahí que se susciten cambios o ajustes de emociones para propiciar un equilibrio, según explica Cuéllar (2020: 266). Así, los interlocutores con mayor poder o estatus motivarán emociones positivas como la alegría, o negativas como la culpa, la vergüenza y el miedo.

En otro orden de ideas, Le Breton declara que "las emociones son modos de afiliación a una comunidad social, una forma de reconocerse y de poder comunicar juntos, bajo un fondo emocional próximo" (Le Breton, 2012: 71). También aclara que "la emoción es a la vez interpretación, expresión, significación, relación, regulación de un intercambio; se modifica de acuerdo con el público, el contexto, se diferencia en su intensidad, e incluso en sus manifestaciones, de acuerdo con la singularidad de cada persona” (2012: 75).

Se han hecho diversas propuestas de clasificación de las emociones. Hay quienes basándose en el componente evaluativo las dividen en positivas, negativas, neutras, mixtas, agradables, desagradables, por citar algunas. Otros, en individuales o colectivas. Y algunos más, en adquiridas o innatas. Sin embargo, en este estudio no se considera si las emociones son buenas o malas, sino qué tan necesarias resultan para asegurar el bienestar del sintiente, preparándolo para ofrecer una respuesta conductual adecuada a cada situación. Así, también se observa la forma como se comparten las emociones y si se devela el "contagio" de algunas de ellas entre los interlocutores. Hay que recordar que, de acuerdo con Rimé, el contagio emocional se da cuando la emoción del sintiente se extiende a las personas a su alrededor. Desde luego, para ello deben darse ciertas condiciones, como la presencia de "rasgos o preocupaciones comunes", así como "lazos de afecto familiares o cercanía física o psicológica” (Rimé, 2012: 150-154).

EntreDiversidades. Revista de Ciencias Sociales y Humanidades, Vol. 9, Núm. 1 (18), enero-junio 2022. Páginas: 272-297 ISSN-e: 2007-7610. https://doi.org/10.31644/ED.V9.N1.2022.A11 


\section{Consideraciones metodológicas}

De acuerdo con Ahmed (2015: 24), más que pensar en lo que son las emociones, la pregunta es "qué hacen". Por tanto, el terreno para el análisis es, en este caso, el discurso que condensa la emocionalidad de los sujetos. Luego entonces, es fundamental la reconstrucción de las condiciones de producción de los discursos, pues permite entender quiénes expresan qué emoción, por qué y en qué circunstancias. Esto nos ayudará a identificar lo que las dolientes experimentaron ante el suicidio de un familiar, su poder y estatus en la comunidad, las causas que originaron ciertas emociones, así como las modificaciones en la dinámica social a que dieron lugar.

En este estudio, para el abordaje empírico de las emociones se seleccionaron tres entrevistas en profundidad concedidas por familiares de suicidas que habitan en una subcomisaría de Mérida, Yucatán, México. ${ }^{3}$ Dichas entrevistas fueron realizadas entre 2006 y 2007. Este material forma parte de una investigación más amplia sobre las percepciones del suicidio en esa zona geográfica. El acercamiento a estas mujeres se hizo a través de la entonces subcomisaria ejidal, quien además de conocer bien a la población sabía de los suicidios ocurridos antes y durante su gestión. Los nombres de las entrevistadas se cambiaron para proteger su identidad, ya que se trata de un tema muy sensible para ellas. Ahora bien, las tres mujeres tienen en común la pérdida de un ser querido por ahorcamiento; ${ }^{4}$ en el caso de Alba, su esposo, en el de Martha, su hijo, y en el caso de Juana, dos de sus hijos y un nieto, con diferencia de un ańo aproximadamente. Es importante señalar que Martha era la suegra de Alba, su inclusión es relevante para ilustrar sus diferentes percepciones a partir de su experiencia y estatus social. A continuación se presenta una breve semblanza de cada una de las entrevistadas.

Alba es originaria de la subcomisaría de estudio, pertenece a una familia de seis integrantes: los padres, una hermana y dos hermanos. Ella es la más joven de todos. En la fecha de la entrevista tenía 18 ańos; cuando su pareja se suicidó tenía 17 y él 19. Se efectuaron dos entrevistas, de entre 40 y 60 minutos cada una, con diferencia de una semana y media entre ambas. La primera se llevó a cabo el 30 de marzo de 2007 en la sala de la casa de sus padres. Entonces trabajaba como costurera en una maquiladora de ropa, empleo que dejó después de unos meses de la muerte de su pareja.

\footnotetext{
${ }^{3}$ El municipio de Mérida se divide en comisarías y subcomisarías para facilitar la administración de las poblaciones rurales. En este caso, la subcomisaría de estudio se ubica a nueve kilómetros del centro de la Ciudad de Mérida. Cuando se realizó el estudio la subcomisaría tenía el 50\% de sus calles pavimentadas, 20\% de las cuales con banqueta. Solo el $80 \%$ de la población contaba con electrificación, alumbrado público y agua potable. En ese momento había 1050 pobladores. De las 108 familias encuestadas, el 9\% de los adultos eran analfabetos y el 57\% solo había estudiado la primaria, algunos de los cuales únicamente cursaron el primero o segundo grado. En cuanto a la cuestión laboral, el 23\% de los varones de dichas familias se dedicaban a la albańilería, el 3\% trabajaba como ayudante de albañil y cerca del 10\% estaban empleados como obreros, jardineros, choferes, veladores, pintores de brocha gorda, mecánicos, mozos, dinamiteros y un fosero (que limpia las fosas sépticas). Casi el 13\% de dichas familias se sostenía con un ingreso mensual de entre $\$ 1200.00$ a $\$ 2000.00$; casi el $27 \%$ de ellas con un ingreso de $\$ 2001.00$ a $\$ 3000.00$, y un 33\% con $\$ 3000.00$ a $\$ 5000.00$. De entre los entrevistados, casi el $51 \%$ de los varones jóvenes y adultos consumían bebidas embriagantes y otro tanto, estupefacientes (Hernández, 2014: 43-74).

${ }^{4}$ Un gran porcentaje de los suicidios ocurridos en Yucatán es por ahorcamiento y los instrumentos más utilizados, según los informantes, son sogas de vinil o la hamaca (que cuelgan al hamaquero), la regadera del baño o una planta (árbol); en la comunidad de estudio existe una cierta propensión por las "matas de tamarindo" (Hernández, 2010: 247). Es de señalar que también prefieren decir "planta" o "mata", para referirse a un árbol.
}

EntreDiversidades. Revista de Ciencias Sociales y Humanidades, Vol. 9, Núm. 1 (18), enero-junio 2022. Páginas: 272-297 ISSN-e: 2007-7610. https://doi.org/10.31644/ED.V9.N1.2022.A11 
Martha, suegra de Alba, es originaria de Cacalchén, Yucatán. Es una señora de 52 años. Se separó de su esposo, pues él andaba con otra mujer. Vive con una nueva pareja y uno de sus cuatro hijos del primer matrimonio. El tercero de sus hijos ya no vivía con ella cuando se suicidó, tenía 19 ańos. Casi un año después del suicidio, se le entrevistó en tres ocasiones, de 20 a 40 minutos, debido a su variable disposición de tiempo.

Juana es originaria de la comunidad de estudio. Es una mujer de 72 años. Vivía con su esposo de 77 ańos (ya falleció) y un hijo soltero, de los 12 que engendró. Se suicidaron su hijo mayor, de 55 años; el menor, de 24, y un nieto. Otros dos de sus hijos fallecieron por cirrosis. Su esposo vendía botellas de vidrio y de plástico que recolectaba en la calle; lo que servía para la manutención familiar. Por su parte, Juana vendía semillas de calabaza que empacaba cuidadosamente en pequeñas bolsitas de plástico. A ella se le entrevistó en cuatro ocasiones, de 40 a 60 minutos cada una, debido a su gran disposición de tiempo para compartir sus experiencias; la primera se llevó a cabo el 28 de febrero de 2007, a un año del último suicidio de sus familiares.

\section{Procedimiento analítico}

Para el análisis de las entrevistas partimos de la idea de que la emoción no puede ser cabalmente investigada si no se atiende al lenguaje y al contexto específico en el que se experimenta y expresa. Siguiendo a Lutz y Abu-Lughod (1990), "si las emociones son consideradas como fenómenos sociales, entonces el discurso es crucial para entender cómo se constituyen” (1990: 11). Las autoras también asumen que el estudio de las emociones, a través del discurso verbal y no verbal, permite interpretarlas como algo que ocurre al interior de la vida social y que tiene efectos en esta realidad.

Para identificar las emociones, así como los recorridos emocionales de las entrevistadas, nos basamos en la técnica de tres vías de Plantin (2014): "La vía directa: la emoción es declarada, anunciada, en un enunciado de emoción explícito. Y las dos vías indirectas, cuando la emoción se afirma indirectamente, el enunciado de emoción debe ser reconstruido” (2014: 161). Estas últimas se hacen a través de las "señales a posteriori de la emoción, es decir, los informes psíquicos y los modos de comportamiento perceptibles característicos de una persona emocionada (manifestaciones fisiológicas, las mimo-posturo-gestuales o conductuales)" (2014: 161). Entre las fisiológicas podemos encontrar la sudoración, el rubor, la aceleración del corazón, dilatación de las pupilas, entre otras tantas. Por otra parte, se consideran las "señales a priori que dan cuenta de la situación dentro de un formato narrativo-descriptivo adecuado para inducir una u otra clase de emoción” (2014: 161).

Mediante el análisis se trata de reconstruir cómo van surgiendo diferentes emociones en el discurso de las mujeres sintientes para identificar su trasfondo social, así como desembrollar el soporte emocional de las experiencias en cada caso. Ahora bien, además de los marcadores emocionales anteriormente propuestos, para poder vincular dichas emociones con el suicidio se ubican marcadores a partir de tres componentes entrelazados de las secuencias emocionales que aparecen en las entrevistas de acuerdo con Scheff (1990, citado en Mancini, 2016: 205):

EntreDiversidades. Revista de Ciencias Sociales y Humanidades, Vol. 9, Núm. 1 (18), enero-junio 2022. Páginas: 272-297 ISSN-e: 2007-7610. https://doi.org/10.31644/ED.V9.N1.2022.A11 
- Atribución causal de la emoción (constituida por los elementos interpelados por estas emociones): quién, quiénes o qué elementos —especialmente en términos de poder y estatusdisparan el contenido emocional de los fragmentos de dichos relatos. Se trata de ubicar los posibles predictores de tales emociones desde una dimensión reflexiva: qué valoración realizan de cada uno de los factores o dispositivos del entorno que condicionan sus emociones.

- Afectación social de la emoción: a quiénes y de qué manera afecta la experiencia emocional respecto de sus vínculos sociales más o menos inmediatos. Cómo definen la situación social que están atravesando, cómo se percibe la mirada de los otros y qué resultados genera ello para la interacción y la nueva situación social —en cuanto nuevo (des)equilibrio social— que emerge a partir de dichas experiencias emocionales.

- Funciones sociales que emanan de esta condición emocional, en términos de la regulación y el control social que suponen (especialmente desde los mecanismos de compensación, reparación y el castigo impuesto), de la censura que generan y de las posibilidades (o no) de conflicto social a partir de su manifestación.

\section{Itinerarios emocionales ante un suicidio}

A continuación, se presenta el análisis de las entrevistas para mostrar la secuencia de emociones que un suicidio desencadena en los deudos. Ya que se trata de relatos de mujeres, es fundamental tomar en consideración la distribución desigual de poderes, factor que parece tener un gran peso a la hora de configurar las relaciones en dicha comunidad, donde no es de sorprender que el capital social ${ }^{5}$ de estas tres mujeres sea menor al de casi cualquier hombre, y que las dinámicas de regulación o control social recaigan, de manera principal, en ellas. Después, el producto de las tres entrevistas se agrupa en dos casos en particular para su análisis: el primero tiene que ver con el relato de Alba ante el suicidio de su esposo, y con el de Martha, la madre del chico. El segundo caso es el de Juana, quien perdió a dos de sus hijos y a un nieto.

\section{El caso de Alba}

En vísperas de Navidad, Alba y su esposo habían acordado viajar a la ciudad de Mérida al terminar su jornada laboral, visitar el centro y hacer algunas compras. Cuando ella llegó del trabajo lo encontró en la calle ingiriendo bebidas embriagantes con sus amigos, pasando por alto el compromiso que tenía con ella. Discutieron y pelearon como nunca; ella asegura que jamás lo había visto tan enojado.

Tomó con sus amigos [...] empezamos a pelear [...] lo desconocí [...] una pelea muy fea [...] que no sé... [Mientras narra, su mirada parece lejana, enfocada en aquel pasado. Toma un momento largo para tragar saliva]. No me pegó, pero sí me insultó, me tiró en el piso, agarró un cuchillo, me dijo que me iba a matar... [Vuelve a tragar, se queda pensativa y trata de

\footnotetext{
5 "El capital social entendido a partir de las redes de relaciones personales que el individuo es capaz de desplegar"
} (Garzón, 2006: 5).

EntreDiversidades. Revista de Ciencias Sociales y Humanidades, Vol. 9, Núm. 1 (18), enero-junio 2022. Páginas: 272-297 ISSN-e: 2007-7610. https://doi.org/10.31644/ED.V9.N1.2022.A11 
recuperarse, para continuar su discurso]. Jamás [...] ahí lo desconocí. Pensé que estaba drogado, pero no estaba; hicieron su autopsia, pero no. Eso sí, estaba alcoholizado.

Su discurso, gestos, tono de voz y los silencios para recuperar la tranquilidad aún reflejan el miedo que le produjo tal situación. El miedo se introyecta al percibir la amenaza del peligro. En ese momento estaba a merced de la voluntad de su pareja, quien mostraba una conducta radicalmente distinta, extremadamente agresiva, empuñando un cuchillo con el que la amagaba, como si se tratase de otro hombre, posiblemente por el influjo del alcohol. La joven en el piso, con el arma blanca apuntándole, se sentía vulnerable e indefensa.

Más adelante en su relato, su miedo es desplazado por ira, al comentar que después de la discusión el muchacho salió al monte (por la parte trasera de la casa):

Ajá, ahí cuando salí, ahí lo vi, estaba... me dio coraje lo que [...] en el que entré, no estaba. Me dice su tío: “¿No está? Me dijeron que sí está. Es que necesito hablar con él”. [Y prosigue:] “¡Ah, ahorita veo!”. Cuando lo fui a hablar vi que no estaba, me lo empezó a hacer [con esto indica que no era la primera vez que lo hacía][...] en que se molesta se va atrás...

Según explica ella, irse al monte también era una costumbre del padre del muchacho, el cual tras una discusión con la madre se iba al monte, desde donde la amenazaba con quitarse la vida. Este hábito era bien conocido por su pareja, quien en ocasiones de enojo imitaba a su progenitor.

Y, en efecto, el muchacho se fue al monte, donde se colgó de una "mata” y murió. "Ajá, ahí cuando salí, ahí lo vi, estaba [...] me dio coraje lo que...”. Los gestos y el tono de voz de la muchacha revelan ira, emoción generada por el estrés y la gran tensión suscitada por las demandas, amenazas y humillaciones recibidas de parte de su familia política (la madre del muchacho, tíos y tías), quienes la culparon del ahorcamiento del muchacho por no haber ido a buscarlo antes al monte. A ello se suma su enojo, provocado por el muchacho, quien la privó de la comunicación e hizo inasequible la reconciliación, y el haberla dejado en una situación tan desventajosa, no solo con la familia política sino con la comunidad. Tras el suicidio de su pareja emergieron conflictos familiares que la obligaron a meter sus cosas en una bolsa y salir prácticamente huyendo de la casa de los parientes del muchacho, con quienes ambos vivían; de esta manera, ella queda en una situación de vulnerabilidad, tanto emocional como social. Sobra enumerar el cúmulo de emociones que revivió la joven en tan solo unos instantes: el miedo, la ira, una gran tristeza y, desde luego, cierta frustración por no haber recobrado la comunicación con su pareja y haber intentado resolver el problema.

En su relato también surgen la vergüenza y la culpa, emociones situacionales generadas a partir de algo ocurrido en el pasado (Ahmed, 2015: 172 y 292). Por su parte, a partir de las consideraciones de Kaufman, Mancini (2016: 196) afirma que "ambas son emociones indisociables, superpuestas, próximas, interrelacionadas y experimentadas de manera concomitante". Estas son culminantes en el ejercicio del control social y, aunque operan de manera distinta, ambas permiten mantener el rango y la jerarquía de los actuantes.

EntreDiversidades. Revista de Ciencias Sociales y Humanidades, Vol. 9, Núm. 1 (18), enero-junio 2022. Páginas: 272-297 ISSN-e: 2007-7610. https://doi.org/10.31644/ED.V9.N1.2022.A11 
De acuerdo con Scheff (1988), "la vergüenza habla de la manera como construimos la percepción que se tiene de nosotros mismos, a partir de la percepción social de los otros: el self social" (1988: 398). ${ }^{6}$ Para identificar algunas situaciones que convocan emociones en Alba, se retoma otro extracto de una de sus entrevistas, un año después del suicidio de su esposo. Tras dicho acontecimiento, la joven menciona que la familia de él y la gente de la comunidad la señalaron — "hablotean" [hablan mal de ella], explica—, no solo por el suicidio de su pareja sino también por eventos anteriores, como el hecho de haberse ido a vivir a casa de la familia de él sin haberse casado, obviando una estricta norma social que deben cumplir las jóvenes de la comunidad.

\begin{abstract}
¡No, me empezaron a decir cosas! "Sólo se murió ese, está empezando a loquear [...] está andando así”. Pendejadas así, a mí no me interesa, es que la gente te juzga de todo, de todo. Así cuando me fui a vivir con él, así dijeron cosas: "Que estoy embarazada, que por eso me fui”, hasta mi mamá me dijo: “QQué!, ¿̇estás embarazada?”. Entonces [...] “De tres meses me vas a ver, porque a los tres meses se empieza a notar, si ves que estoy embarazada", es por eso que me fui y [...] "pero si ves que no" $[\ldots]$ y ahí está $[\ldots]$ pasó. "Te estoy diciendo que no estoy embarazada".

Pasó eso, lo mismo: "que me vieron con mi querido, que no sé qué [...]", un montón de cosas. ¿QQué no me dijeron?! Ya estoy acostumbrada que la gente hable mal de mí. La gente habla, pero no ve su cola también; aunque sea chiquita tenemos cola que nos pisen.
\end{abstract}

El suicidio de su esposo convierte a Alba en el foco de atención de la comunidad, que se constituye como autoridad para ponerla bajo escrutinio y "avergonzarla". La situación de vulnerabilidad a la que se enfrenta devela una gran asimetría, ya que no cuenta con algún tipo de capital (social, económico ${ }^{7}$ o simbólico ${ }^{8}$ ) que la proteja. Su estado de indefensión se puede mirar desde varios ángulos. Por un lado, está el factor situacional: mujer, sola, en casa de los parientes del joven, donde ellos, junto con los vecinos del muchacho, son los primeros en cuestionarla, insultarla, lastimarla y culparla. Su pareja, único lazo que la unía a ellos, ya no existe. Por otro lado, está el grupo etario al que pertenece: es una menor de edad entre muchos adultos. Amén de lo anterior, su situación social la deja aún más débil, pues no estaba casada al momento del suicidio de su pareja, lo que constituye una grave falta moral en la comunidad. Por tanto, aun cuando hay otros casos de unión libre en la comunidad, siempre ha existido la posibilidad de ser víctima de una doble moral social, principalmente por la suma de factores adversos a los que se enfrentaba. Hay que tener en cuenta que en su nuevo contexto ya no tiene un hombre que la defienda, lo que implica la pérdida de derechos ante la familia política y los vecinos, debido al juicio de la comunidad.

\footnotetext{
${ }^{6}$ Trad. propia: "shame is the social emotion, arising as it does out of he monitoring of one's own actions by viewing one's self from the standpoint of others" (Scheff, 1988: 398).

7 "El capital económico se define por los bienes materiales de producción y de consumo de los agentes. Se puede visualizar en los bienes patrimoniales que los padres acumulan y dejan en heredad a sus hijos como un recurso que los empodera y los distingue en las personas de su generación, y los hace competir por un lugar de renombre en la escala social" (Fowler y Zavaleta, 2013: 124).

8 "Cualquier diferencia que sea reconocida, aceptada como legítima, funciona por el mismísimo hecho como un capital simbólico, proveyendo una prueba de distinción” (Bourdieu, 2013: 6).
}

EntreDiversidades. Revista de Ciencias Sociales y Humanidades, Vol. 9, Núm. 1 (18), enero-junio 2022. Páginas: 272-297 ISSN-e: 2007-7610. https://doi.org/10.31644/ED.V9.N1.2022.A11 
Alba es consciente de que sus vínculos sociales son inseguros, ya que ha transgredido ciertos lineamientos de la subcomisaría y estos han sido censurados no solo por la comunidad, sino por su madre también. Durante la entrevista, ella expresa una lista de agravios que ha sufrido y que han dejado huella en su vida; quizá la más profunda sea la que imprimió su propia progenitora, dado el parentesco y el afecto que le tiene a su madre. Esto es lo que Hansberg (1996: 161) llamaría "vergüenza moral", donde están en juego los valores y las exigencias morales ideales. En el caso que nos ocupa, el ideal en la comunidad es que una joven salga de casa de los padres vestida de blanco, directo al altar antes de consumar el matrimonio, y que consagre el resto de su vida al cuidado del esposo y los hijos; aunque esto no siempre se cumple, tampoco se juzga con tanto énfasis como lo hicieron con Alba tras el suicidio de su pareja. Sin embargo, al declarar que todos "tenemos cola que nos pisen" (así, de manera incluyente) se anticipa a enfrentar a quienes le dirijan más reproches, además de marcar una diferencia y distancia social suficiente que le permita posicionarse ante la supuesta superioridad de los demás para evitar cualquier acción de estigmatización o degradación. Esto actúa como una estrategia de regulación interpersonal positiva, disminuyendo un poco las emociones negativas, al tiempo de propiciarle algo de calma y esperanza. Podría considerarse como un intento de recuperar el vínculo social con su comunidad, apelar a la aceptación de la gente (o por lo menos a su silencio) y a la posibilidad de reconstrucción de sus relaciones sociales, pues en dichas circunstancias su única alternativa fue mudarse de la casa de los parientes del muchacho a la de sus padres, ya que no tenía los medios para emigrar de la subcomisaría como ella hubiera deseado.

Aunque la joven repite con determinación y enojo las situaciones que produjeron los comentarios de la gente en el pasado y en su discurso verbal aparenta no importarle el rechazo y la desaprobación de los demás, las manifestaciones fisiológicas de su cuerpo y su postura aún revelan vergüenza. Alba baja la cabeza y desvía la mirada, al tiempo de romper en llanto. Esa misma emoción, especie de "miedo a la degradación social o, dicho en términos más generales, a los gestos de superioridad de los otros” (Elias, 2015: 499) y quizá también al conocimiento de su incapacidad para defenderse de amenazas exteriores como de los parientes políticos y miembros de la comunidad, hizo que la joven saliera de la casa de la familia política la noche de la muerte de su pareja y fuera a refugiarse en un lugar libre de la mirada de la gente, la casa de sus padres. La afectación social fue mucho más allá de la interacción en la que se produjo dicha emoción, ya que Alba permaneció encerrada en la casa familiar hasta muchos meses después. Su actitud desvela cómo lo social es legitimado, incorporado y reproducido por ella.

Durante su reclusión en casa de los padres Alba tiene ocasión de analizar la situación con detenimiento y es entonces cuando emerge la culpa, que tal como Mancini (2016: 196) explica interpretando a Harré y Lamb, esta es una"condición atribuida a una persona (especialmente a uno mismo, al self) a raíz de alguna transgresión moral, que se experimenta cuando se produce una violación (generalmente bajo un comportamiento egoísta) de un principio altamente valorado (por uno y por los demás)". Siente una gran responsabilidad por la discusión sostenida con su pareja. Como no puede reparar el dańo, expresa un cierto remordimiento al pensar una y otra vez en lo que habría ocurrido si hubiera actuado de forma distinta. Ella acepta la responsabilidad de no haber platicado con su pareja para tratar de solucionar las cosas: "Pues [...] ¡Ay! ¿Cómo

EntreDiversidades. Revista de Ciencias Sociales y Humanidades, Vol. 9, Núm. 1 (18), enero-junio 2022. Páginas: 272-297 ISSN-e: 2007-7610. https://doi.org/10.31644/ED.V9.N1.2022.A11 
le diré? Si hubiese sabido que iba a intentar algo así, pues trataría de no enojarlo mucho, que no [...] que se moleste mucho, así no se va atrás [al monte], iría a verlo, algo así, pero no dijo nada”.

Así, la joven se apropia de la culpa que los parientes y algunos vecinos de la comunidad han depositado en ella por no haber ido a buscar al muchacho cuando el tío fue a su casa a preguntar por él. Reconoce la afectación a los familiares del muchacho y el costo que conlleva en la interacción social de la localidad: "Si le hubiera ido a hablar cuando me dijeron, tal vez se hubiera salvado. Quién sabe, eso es lo que dicen”. No obstante, para cambiar el foco de las miradas, crear una "cortina de humo" y quizá así aminorar un poco el peso de dicha emoción, distribuye parte de la culpa entre diferentes actores. Por un lado, el ejemplo de los padres de él, cuyo comportamiento juzga egoísta, por no considerar los sentimientos de los hijos.

¿Cómo le diré? Sus papás no vivían juntos, vivían separados y, ya ve, no me lo decía, pero me daba yo cuenta. Como su mamá tiene otra pareja [...] El señor se casó, es lo que él me dijo, fue lo que más le dolió; su papá nunca se casó con su mamá, buscó el señor a otra y con ella se casó. Me dice su mamá: "En que sale se molesta, sale en la parte de atrás, está molesto". Cuando el entierro [...] su papá dijo: "Tú te fuiste [...]", dio a entender que así lo quiso hacer su hijo; llegó a hacer lo que su papá hacía y eso hizo también. Cuando su esposo se molestaba [...] se molesta y se va. Una vez se molestó conmigo y le dijo la señora: "estás haciendo lo que tu papá hacía cuando se enojaba” [...] la señora le decía: “Ay, estás haciendo lo que tu papá hacía!” [...] no le contestaba.

Y, por supuesto, también deposita un poco de culpa en el muchacho, cuya ira lo llevó a transgredir el principio de respeto hacia ella al tirarla y amenazarla con un arma blanca. "'Óyeme’, le dije. ¿QQué te está pasando? ¡Te estás alterando demasiado!', le dije. Él se dio cuenta. ‘¡Perdóname!', dijo, salió en la parte de atrás [...] ¿Cómo voy a saber que iba a hacer eso?”.

Después de la repartición de culpas, Alba vuelve la mirada a la ocurrencia de hechos en la subcomisaría y retoma el miedo. Este miedo en particular, distinto al anterior, le proporciona una cierta regulación interpersonal, ya que le permite tornar la atención a cada miembro de la comunidad, pues todos están expuestos. Sabe que esta afectación actúa como una "epidemia", un contagio que se propaga rápidamente si no se toman las medidas necesarias para el caso. Ahora todos se enfrentan a lo desconocido, a algo superior, intangible, amenazante, que puede propagarse y atacar a cualquiera. Introduce esta parte del discurso con una invocación a Dios, quizá como una forma de protección contra ese "Mal" que ha atacado a diferentes actores de la comunidad.

¡Ay, Dios mío [Utiliza un tono suplicante y hace una pausa antes de continuar], aquí estuvo mucho esa epidemia! Se suicidaron muchos [...] una muchachita de 14 años se suicidó también. Tiene dos años eso, de marzo que falleció esa muchacha. Después en diciembre, después otro en marzo, abril, para junio su hermanito. Solo eso estuvo pasando aquí o que se pasaban a suicidar [...] Esas cosas, no sé por qué lo hacen... y viene la epidemia acá [...] y ya [...] puras cosas que están pasando.

EntreDiversidades. Revista de Ciencias Sociales y Humanidades, Vol. 9, Núm. 1 (18), enero-junio 2022. Páginas: 272-297 ISSN-e: 2007-7610. https://doi.org/10.31644/ED.V9.N1.2022.A11 
Desde luego, la propagación del miedo a dicha "epidemia", tal como lo expresaron dos de las entrevistadas y algunos vecinos, se convierte en la tarea de los parientes y amigos, para que la gente de la comunidad se preocupe y ocupe de esta amenaza en lugar de seguir señalando culpables.

\section{El caso de Martha}

Madre del joven de 19 años, también experimenta diferentes emociones a partir del suicidio de su hijo. Cuando narra lo sucedido, de acuerdo con la información que le dio la pareja del muchacho (Alba), se puede observar cierta ira en ella.

¡¿La muchacha esa?! Sí le pregunté. ¡Ah, es que estuvo habloteando, que no sé qué [...], que por acá [...]! Bueno, tiene que buscar defenderse ella, pero como dije: "Sabes lo que ya pasó, no me voy a poner a pelear, pero sí me duele mucho". Lo único que yo digo: que se quede en las manos de Dios, Él va a hacer justicia, que se quede en las manos de Dios. Si ella tuvo la culpa o no tuvo la culpa, allá ella, ¿para qué voy a poner a pelear? Si voy a pelear no va a volver... ¿Para qué?

En este momento de la entrevista Martha se refiere a Alba como la "muchacha esa", en tono despectivo. También demuestra y refuerza su coraje al utilizar el término peyorativo "habloteando" para referirse a que, según ella, Alba cuenta cosas negativas o inciertas. Por otra parte, su discurso condenatorio revela cierto resentimiento, reproche y responsabilidad de la que fuera su nuera por el suicidio de su hijo, al decir que ella "busca defenderse", aunque más adelante se deslinda del señalamiento dejando todo "en las manos de Dios".

Más adelante declara lo que supone pensó su hijo. En ese punto prefiere referirse a la muchacha a través de un adjetivo demostrativo, en lugar de su nombre, como una forma de marcar distancia e indicar cierto resentimiento:

“AAh! Si yo busco problema a esta, pues que se quede y yo me voy”. Y creo que no le vino a la mente, pues creo que fue algo fuerte para él, que creo que no le vino en la mente... o le dijeron por esta... o hicieron por esta. Hay parejas que así pasa, se ponen a discutir, a tomar o se ponen a hacer otras cosas, pero él... creo que pensó eso.

Su ira es más evidente cuando recuerda cómo a la hora del entierro de su hijo algunos miembros de la comunidad impedían que se le enterrara boca arriba por haber cometido suicidio; alegaban que debía quedar de costado o boca abajo, sin mostrar la cara a Dios, por despreciar la vida que le había dado. En otro caso de suicidio de la subcomisaría, los vecinos incluso negaron la entrada del cadáver al Camposanto. Uno de ellos argumentó que por ser un sitio sagrado no se puede enterrar ahí a una persona que rechaza la vida, ya que es un "regalo que Dios da y solo Él puede quitar".

Mientras relata cómo algunos integrantes de la comunidad querían que su hijo fuera enterrado boca abajo y explica su actitud para no atender sus demandas, su discurso no verbal revela una gran frustración ante la situación vivida, así como animadversión hacia algunos actores de la población, quizá por su falta de empatía. Aunque parece muy convencida de lo que dice, no

EntreDiversidades. Revista de Ciencias Sociales y Humanidades, Vol. 9, Núm. 1 (18), enero-junio 2022. Páginas: 272-297 ISSN-e: 2007-7610. https://doi.org/10.31644/ED.V9.N1.2022.A11 
hace contacto visual al comentarlo, como si el eco de la experiencia emocional, provocada por los seńalamientos de la población se lo impidiera.

Yo quiero que como esté se vaya, que tal si... ¿cómo le puedo decir a usted?, ¿qué tal si le quiere ver la cara Diosito cuando llegue allá? Va a esconder su cara. Porque muchos me estaban diciendo que lo pongan boca abajo. A pesar de lo que haya hecho, él no hizo algo malo. Sabe, como le había dicho, mi hijo no está allá alborotando con los vecinos, peleando con cualquiera. Está bien, ¿sabes?, que eso que le perdone Dios. Yo soy su madre, así está, así se va a quedar, no quiero que lo pongan como dicen.

Lo anterior se refuerza con la siguiente sección de la entrevista en la que ella defiende a su hijo, aunque la ira inicial cede paso rápidamente a la tristeza. El dolor emocional que surge tras dicho evento lamentable hace presa de ella nuevamente, ahora ante los recuerdos de su hijo fallecido.

Pero yo sé que está perdonado por Dios, yo sé qué pienso... y yo sé que es así. Tal vez lo que hizo en ese momento, pero su corazón no era malo, su alma no es mala. Es buena gente mi hijo, simplemente tuvo ese problema y cometió ese error de quitarse la vida. Yo sé cómo es él... como es él.

Y prosigue, con voz entrecortada, víctima de las lágrimas, muestra del dolor y profunda tristeza que le ocasionan la separación de su hijo y los recuerdos que la acompañan:

¡Fue terrible! Un momento tan terrible en mi vida... Digo entre mí, hasta ahora cuando lo recuerdo, no sé [...] siento que me destroza el corazón, no se me olvida, bueno... [No puede contener el llanto].

Entonces que no se me quita de la mente, me dicen, me pongo a llorar, ni modo, me duele, es mi hijo, todavía me duele. "Pues ten paz [...] pídele a Dios" [Le dice la gente]. Es lo que yo hago [...] pedirle a Dios, que donde esté que lo cuide, que no lo abandone y todo eso.

Más adelante, la vergüenza moral y la culpa parecen amalgamarse cuando la madre trata de explicar el suicidio de su hijo, al tiempo que intenta esclarecer lo que lo pudo llevar a tomar dicha decisión. El suicidio del joven puso a Martha en una situación de vulnerabilidad. La gente de la comunidad primero dirigió la mirada al muchacho y después a cada uno de los familiares, de manera que sus historias de vida quedaron a disposición de la (d)evaluación de la comunidad. La reconstrucción afectiva, derivada de sus recuerdos, hace presa nuevamente de sus emociones. En su discurso, la madre del muchacho enfrenta la alternativa de quedarse callada ante los ojos inquisitivos de los pobladores o verbalizar lo que supone parte de su "responsabilidad" de acuerdo con lo que la gente señaló. Martha rompe el silencio y, quizá como una manera de regular sus pensamientos, enumera una a una las faltas que le han atribuido.

La madre revela estar separada de su esposo, vivir con una nueva pareja y no haber estado cuando su hijo la necesitaba, tras la discusión con Alba. Su declaración remite a comportamientos 
femeninos socialmente sancionados por la gente de la comunidad en la que vive, lo que le ocasiona cierta vergüenza, al grado de mantener al margen la identidad de su pareja actual. No obstante, para contrarrestar dichos seńalamientos y marcar una distancia respecto de quienes la culpan, de manera que le permita evitar la degradación social, subraya su sentido de responsabilidad y cuidados para con sus hijos tras el abandono del padre. Este último argumento es un modo de diferenciación que le permite apartarse de la construcción moral de otros grupos menospreciados: como el de las mujeres que dejan al marido y las que abandonan a los hijos, por ejemplo.

Así, a través de dichas revelaciones legitima, incorpora y reproduce el discurso social, al tiempo que apela al perdón de la población al reconocer "su falta", por no haber estado con su hijo en un momento en el que la necesitaba, además de sugerir un intento de su parte por recuperar su vínculo con la sociedad. Asimismo, en su discurso deja entrever otros actores que de alguna manera pudieron afectar la decisión de su hijo. Dicha repartición de culpas puede hacer las veces de regulación interpersonal.

El suicidio es... pues algún problema que creo tienen los jóvenes, ¿̨verdad? Hasta los mayores [...] las personas adultas como nosotras, ¿verdad? [involucra a la interlocutora, como buscando empatía]. Algún problema creo, en el caso mío, que le pasó a mi hijo. Eso, no sé, tenía a su pareja, tenía 19 años, apenas cumplió 19 años, el 16 diciembre cumplió 18 años, entonces 19, así [...] Yo no estaba acá cuando pasó eso... Como el papá de mis hijos también se fue con otra señora... Vive acá [seńala el lugar]. Entonces yo me quedé con ellos, entonces tengo otra pareja. En la fiesta de la Navidad y todo eso me dice mi pareja, como allá vive mi papá, “¿por qué no vas a pasear con tu papá?”, me dice él. Bueno, estoy tan segura, que es como que usted tenga un hijo, ya está con su mujer, lo va a cuidar, va a estar bien, en eso agarré, fui a Cacalchén. Entonces llegando a Cacalchén, ahí está, resulta que en la noche viene mi hijo grande, me da la mala noticia que sucedió con mi hijo [...].

En esta parte de la entrevista, primero se deslinda de cierta manera de la responsabilidad de no haber estado en la subcomisaría cuando su hijo se suicidó. Más adelante, enfatiza el abandono del padre, situación que da a entender podría haber propiciado el descuido a la familia y la inseguridad emocional. Y, antes de aclarar que ella también tiene otra pareja, recalca que se hizo cargo de los hijos, en un intento personal de mitigar la culpa o escapar al señalamiento de la gente. Al relatar este último fragmento corren lágrimas por sus mejillas, quizá además de por el dolor por la pérdida de su hijo, por un sentimiento de culpa, sugerida en su discurso, por no haber estado para él en ese momento, así como por la vergüenza de encontrarse con su nueva pareja en otro lugar cuando ocurrió el suceso, lo cual no es bien visto en la subcomisaría, según sugiere en su relato.

A veces digo yo así: Si ese momento [...] ¿Quién? ¿Quién va a saber las cosas que va a suceder? Si ese momento estuviera yo acá, yo creo que no hubiera pasado o [...] Es lo que digo, a veces si estuviese acá, yo hubiera visto [...], pero ¿quién va a saber las cosas que van a pasar? Y agarré yo fui a ver a mi papá y digo: ¿Por qué pasan esas cosas a mi hijo?, digo entre mí y es lo único.

EntreDiversidades. Revista de Ciencias Sociales y Humanidades, Vol. 9, Núm. 1 (18), enero-junio 2022. Páginas: 272-297 ISSN-e: 2007-7610. https://doi.org/10.31644/ED.V9.N1.2022.A11 
Por otra parte, como en el caso de Alba, aparece el miedo, generado por un ente superior, un "Ser" maligno, al que no ve. Saben de su existencia, pues ya antes se ha apoderado de algunos pobladores en momentos de debilidad, como cuando han ingerido bebidas embriagantes o consumido drogas, enfrentan algún problema familiar o de salud. Por ello, a partir del suicidio de su hijo es presa del miedo, pues sabe de la presencia de este Ser en la comunidad y la experiencia les ha enseñado que a un evento de dicha naturaleza le siguen otros tantos, propiciados por Él.

Yo creo que sí, porque dicen que esas cosas que suceden así, principalmente esta... El Mal hace esas cosas. Él te hace tomar esa decisión, para tomar la vida. En esa forma el Mal se apoderó de él y tuvo un poco de problemas con la muchacha y todo eso [...] lo que hizo, eso, se apoderó el Mal de él, porque era un chavo bien, mira no era un chavo problemático, no peleaba con nadie.

Es tal el temor que le tiene a ese Ser maligno que prefiere evitar su nombre, lo identifica como el Mal; situación que se replica de la lengua maya, donde se le prefiere llamar Kakaz-baal (cosa muy mala), en lugar de Cizin (Demonio) (Villa, 1995: 184-185). En raras ocasiones, cuando se ve forzada a pronunciar su nombre, lo hace en voz baja, no sin antes mirar a todos lados para asegurarse de que no esté cerca, acechando. Luego, para señalar al responsable, aclara: "El Demonio [le tomó tiempo pronunciar su nombre, no sin antes haber inspeccionado el área con detenimiento], como dicen, eso es... Se acorraló a él mismo”.

Así, tras un suicidio inician los rituales de limpieza o exorcismo ${ }^{9}$ en la comunidad. Entre estos, se incluye el corte de matas, la limpieza con hierbas, la quema de inciensos, la limpieza con agua bendita si el padre lo permite y, desde luego, muchos rezos. El miedo al Mal es compartido por todos, ya que cualquiera puede atravesar momentos de vulnerabilidad y ser presa fácil de este.

Realizar todos los rituales señalados por los parientes y vecinos de la comunidad denota presión y control social, ya que es latente el miedo a ser seńalada, aislada y provocar la desaprobación de los demás actores sociales por no atender las indicaciones de limpieza y liberación del Mal. Además, con ello se previene la ocasión de otro evento de ese tipo porque, de ocurrir otro suicidio, si no hubiera realizado la limpieza, Martha provocaría que la señalaran como responsable. Por otro lado, también sugiere miedo a lo desconocido y lo intangible — que hace que la gente se suicide-, como si se tratase de un hecho fortuito donde no solo se le teme al Mal, sino también a lo que pueda provocar y todo lo que tenga que ver con este, incluyendo el instrumento o medio utilizado. Tal es el caso que al preguntarle cómo se suicidó, responde: "De... [hace el ademán como de una cuerda en su cuello, le acompaña un silencio largo, para asegurarse de que la interlocutora tenga clara la comunicación no verbal] sí, sí, eso es. ¿Cómo es que acá pura de esas cosas están sucediendo ahorita?”.

\footnotetext{
${ }^{9}$ Utilizo este término ya que, de acuerdo con la descripción que dieron los pobladores, se trata de una limpieza para expulsar al demonio del cuerpo de una persona, de algún ser vivo o de un lugar y ahuyentarlo, tanto como sea posible.
}

EntreDiversidades. Revista de Ciencias Sociales y Humanidades, Vol. 9, Núm. 1 (18), enero-junio 2022. Páginas: $272-297$ ISSN-e: 2007-7610. https://doi.org/10.31644/ED.V9.N1.2022.A11 


\section{El caso de Juana}

En el discurso de Juana, madre de dos hijos y un nieto fallecidos por suicidio, también surge una cadena de emociones de la que se da cuenta a continuación. Ella siente ira en diferente intensidad por hechos diversos en los que condena distintas situaciones y actores. Primero, al hablar del "supuesto" suicidio de su nieto, veredicto de las autoridades que pone en entredicho con sus declaraciones. Cada uno de sus cuestionamientos revela cierta frustración por el desconocimiento de los hechos. Además, parece reprochar algo a la pareja del muchacho, de quien discursivamente pone distancia y a la cual se refiere de manera eufemística como "una seńora de la vida", por no mencionar la actividad a la que se dedica.

¡Pero yo no comí esos cuentos, doctora! [expresión utilizada para indicar que no lo creyó], la verdad, porque así se mató ese chiquito, así se mató, y su... como le dicen sofá, donde se sientan ellos. ¿Cómo se cayó y caminó, que se siente y se acomode? Eso no lo creo, la verdad no lo creo, hasta ahorita no lo creo, pero tuvo una señora, "una señora de la vida" [nocturna, una prostituta]... ¿Cómo se reventó la soga, que se caiga? Se caerá embrocado o en un lado o en el otro lado... o se pegaría en la pared. ¿Pero hincado, pero que tenga suficiente fuerza para sentarse? No lo creo eso, cuando lo buscaron seis días de muerto, ya tenía hasta gusanos en su cara, está sentadito en el sofá, tenía puestos sus brazos así [y cruza los brazos para hacer la demostración] y su pie lo tiene cruzado, su chancleta está abajo de su pie... y su cabellera ya está despegado [sic], ya está, su cara no, ya no tenía, ya está desfigurado, ya lo habían comido [los gusanos], de hecho el doctor nos dijo que no, no hizo, claro que, ¿cómo le dicen? El cable lo tenía en su garganta, pero no lo tiene cubierto hasta acá [señala la parte trasera de su cuello], sino que se reventó y el cable que está colgado no es el mismo que tiene en la garganta, porque el cable que está colgado es el del abanico y la que tiene aquí en su garganta era uno negro, entonces no era el mismo cable.

Más adelante, también con mucho coraje, vierte cierto resentimiento hacia su yerno, esposo de su hija y padre de su nieto. Revela el desprecio hacia el señor al designarlo con la palabra altisonante "cabrón", a la que acompaña el término peyorativo "guache" (utilizado para indicar que alguien no es originario del lugar), repetido como un insulto, mientras aclara la forma como el seńor trata a su hija y su opinión de cómo debería comportarse ella con él:

Es albañil... pero mi yerno nunca pudo ver a su hijo... era muy cabrón, guache, es guache... Es de, es de Chiapas, solo vino a... ¿ay, cómo le dicen? Cápora, Crío y de eso vino aquí en Mérida, se enamoró de mi hija, se casaron. ¡Ay, doctora, tiene muy mal carácter! Acaban de operar a mi hija de un nené [bebé] y la encerró mi hija en un miriñaque [tela de alambre que se utiliza como mosquitero].

Mi hija y hasta hoy... no le da dinero, que le da solo diez pesos, veinte pesos diarios... le digo a mi hija... ella trabaja en un lugar y compraba pollo, kilo de pollo lo metía en su refrigerador pa' todos, entonces le digo: "hija, porque sé que le das cosa buena pa’ que coma, entonces ¿por

EntreDiversidades. Revista de Ciencias Sociales y Humanidades, Vol. 9, Núm. 1 (18), enero-junio 2022. Páginas: 272-297 ISSN-e: 2007-7610. https://doi.org/10.31644/ED.V9.N1.2022.A11 
qué se apura él? ¿¿de qué se apura?”. "No", le digo... “castígalo... te está dando 20 pesos, compra medio de huevo, compra medio o un kilo de tortilla, si hubo pa' refresco, si no, pues no... así se va a fastidiar”, pero a mi hija es su adoración, doctora. ¿¿Qué más le puedo hacer?

Otro pasaje que provoca una gran ira en Juana es el de la discusión entre uno de sus hijos y el padre. Su molestia la demuestra a través de las gesticulaciones de enojo que hace al representar cada una de las escenas, así como por los tonos de voz que utiliza, por lo general más altos. Llama la atención cómo Juana resalta la falta de consideración del hijo hacia el padre, más que por la intención de golpearlo por el uso de la segunda persona del singular "tú" en lugar del "usted", pronombre personal muy utilizado todavía en algunas comunidades para referirse a los padres como señal de respeto.

"Hoy se te va a acabar, porque tú le das mala vida a mi madre, toda la vida a mi madre estoy viendo cómo le pegas, cómo le botas sus cosas, cómo no le das dinero, puro tomar haces, igual que yo, pues ahora tú vas a morir o me matas a mî” [conforme avanza su discurso va subiendo el tono de voz]. Entonces, ese día, doctora, no lo dejé... él, como tiene sus regalos de esa Lupita cuando se casó...; vasos le regalaron de esos gruesotes, metió su mano, con eso le iba a dar a su papá y lo iba a pegar hacia la pared y yo no lo dejé. Me metí en medio, jno sé cómo lo hice, que bajé su mano!, y le dije: "aquí no vas a matar a tu papá, primero me quitas a mí, luego tu papá, pero no le vas a hacer nada. ¿Qué te está pasando? ¿Qué estás quedando loco?”, le dije, y dijo: "Loco por defenderte, porque todo lo que le hace mi padre, ¿cree usted que no lo siento?, sí lo siento... pero usted así lo ha querido, ¿verdad?”, me dijo. "No hijo”, le digo, "deja mis problemas con tu papá, tú no te metas, porque todavía puedo pelear mis derechos". "Sí, ya lo sé, ipero tiene que morir!”.

Se levantó, cuando se levantó sobre su papá se fue: "Hoy llegó tu día, hoy te voy a matar, porque ya me fastidié que tú le estás dando mala vida a mi mamá” [...] No le dijo de usted, le dijo: "Tú le das mala vida a mi mamá”.

Juana, al igual que otros miembros de la comunidad, también se muestra muy molesta al comentar que tras el suicidio de sus familiares los del Servicio Médico Forense (SEMEFO) llegaron, se los llevaron y luego los devolvieron "cortados". Según comentarios de varios miembros de otras familias en circunstancias similares, la autopsia de ley no se realiza únicamente para determinar la razón de la defunción, ya que existe una sospecha generalizada (de la que no se conoce la procedencia) de que los trabajadores del SEMEFO están implicados en la venta de órganos de sus parientes. Sin embargo, cuando hablan de ello les parece algo inconcebible, debido a que en algunos casos los del propio servicio han ayudado a bajarlos de la cuerda donde los encuentran pendiendo.

La tristeza reemplaza a la ira y se apodera de Juana cuando empieza a narrar el comportamiento de sus hijos durante los últimos días, antes de cometer suicidio. Es evidente que no le gustaba la forma como vivían; sin embargo, como ella apunta, sola no podía hacer nada para cambiarlo.

EntreDiversidades. Revista de Ciencias Sociales y Humanidades, Vol. 9, Núm. 1 (18), enero-junio 2022. Páginas: $272-297$ ISSN-e: 2007-7610. https://doi.org/10.31644/ED.V9.N1.2022.A11 
Sí tomaba, Amado no, pero Javier sí, porque en su nariz metía una pastillita y ponía hasta adentro, hasta adentro y jalaba y al rato no era él... se va cuando toma eso... se queda así [demuestra gesticulando la mirada perdida del joven], sus ojos diferentes y jjala!... agarra su pomito y se va. Es el que toma mucho, pero de antes nos pasaba a pegar, nos insultaba; pero así de barbaridades, pasaba a pegar a su hermana, trompiaba a su hermano que vive allá [señala con el dedo la dirección], así teníamos que cuidar a su hermano. Pero mira, doctora, cómo le he pedido a Dios [su discurso termina en un llanto].

Más adelante, sin razón aparente, Juana empieza a platicar sobre sus visitas a la iglesia. A manera de justificación, comenta por qué rara vez va a misa. Señala que no es falta de devoción o tiempo lo que se lo impide, sino la vergüenza que pasa frente a la gente del pueblo cada vez que va. Su discurso da cuenta de la relación de estas salidas al templo y la vida de su hijo.

Estaba yo encaminada... llegó la hora de las cinco, pa' la misa [...] y nunca salgo a la misa doctora, nunca en la vida. No puedo, tengo tantos chiquitos [se refiere a sus nietos], pues no me alcanza el tiempo y si voy, ahí van atrás de mí. ¡Ay, qué pena me da que no tienen ropa! ¡Ay, mi vida! Hay quien tiene ropa, hay quienes no tienen ropa... hay veces no tienen ropa, no es chisme, ni es mentira; ahí está, ponen ropa de sus hermanos. ¿Qué ponen los pobres que no tienen ropa?

Esta emoción que siente camino a la iglesia exhibe lo frágiles que son sus vínculos sociales en la subcomisaría. Resiente la desaprobación de los habitantes por su falta de capitales, como el económico, ya que no alcanza a cumplir con ciertas expectativas. La conciencia de su incapacidad para defenderse de las miradas y comentarios de la gente es tan fuerte que prefiere no ir a la iglesia para evitar exponerse al señalamiento y la degradación social.

Continúa el discurso platicando de su hijo más joven, el último que se suicidó. Durante este relato surgen varias emociones entrelazadas. En la sección que sigue revela mucho coraje, mientras ofrece una serie de argumentos para no apoyar la decisión de su hijo.

"Mami, esta Flor va a ser mi novia" [le dijo su hijo, anunciando que esa muchacha sería su pareja, mujer a la que quería llevar a vivir con él, en casa de sus padres]... Pero yo no se lo consentí, doctora, porque... ¿ ¿Sabe usted por qué? Porque veo cómo le escupe en la cara [en sentido figurado]. Veo que el esposo de esta comisaria... ellos venían de casa de dos pisos..., entonces ellos dos vienen acá y ella les acaricia el pelo, les peina el pelo, les pone vaselina, les pone... bueno gel, les pone todo a los muchachos, les empieza a peinar, les prepara horchata... a todos da [todos esos hechos los presenta como gestos de superioridad y quizá discriminación a su hijo]... y a este mi'jo no le dan nada y le digo, a ti no te dan y no te toca porque estás cochino. ¿Qué ha hecho delante de ti con los muchachos? ¿Cómo te escupe la cara, hijo? [en sentido figurado]. Le digo, eso no se hace... si no te quiere pues que te lo diga, que no te quiere... pero menos que te escupa la cara, porque no eres un animal... con un par de bofetadas no lo vuelve a hacer [el hecho de golpear a la mujer es socialmente aceptado por algunos miembros originarios 
de dicha comunidad; lo utilizan como un "correctivo" para tratar de moldear la conducta de la mujer. Lo hacen algunos esposos y en ocasiones, como esta, por sugerencia de sus propias madres, suegras de las mujeres], pero hasta que pase eso [...] mira hijo: “ ¿No te das cuenta, que no te quiere esa muchacha? Con todos habla, con todos se abrazotea, todos lo están jugueteando, es lo que tú no te das cuenta”.

Los argumentos para justificar la decisión de no aceptar a la novia del hijo en su casa evidencian una intención encubierta, ya que no los explicita abiertamente ante los presentes en el funeral y los rezos posteriores. Sin embargo, lo que se puede deducir de ello es que su postura se basa en una emoción cuya atribución causal es prácticamente ajena a la muchacha. Juana siente una gran vergüenza ante la presencia de la joven, por el simple hecho de que viene de la ciudad y vive en una casa de dos pisos, lo que establece un marcador de superioridad de dicha familia. Ella se percibe como una persona de una escala socioeconómica menor que no debe esperar atenciones de las personas con un capital social o económico superior, y quiere que el hijo comparta la misma percepción.Y prosigue su historia contando lo que sucedió mientras estaba escuchando misa:

Vienen unas amigas de mi'ja Oliva y de eso entonces me dijeron: "Hay un muerto en tu casa", me dicen. “¿Cómo que un muerto?”. "Sí, hay un muerto... de los que no toman”. Mi hijo Martín no tomaba... “¿Cómo?”, les dije, "solo me mienten”, les digo. “№!”, me dicen. “¡No, doña Juana, no, es que tienes un muerto en la casa!”. Pero, yo no lo creí doctora, por Dios santito que en ningún momento pasó en mi mente ese Mal... Bueno, cuando yo entré, cuando yo vine, fui corriendo... Siento que estoy corriendo, pero mis pies no se movían. Llegué acá, en esa casa donde está mi’ja y cuando llego veo en la riel... Ahí estaba colgado él, al fondo, está alto. ¡Ay Dios!, ya estaba muerto [...] y yo lo confesé al padre de la catedral y le digo: "Padre, yo quité...", porque yo veo que no lo quiere y es una mujer, es una muchacha muy coqueta y todo...

Las lágrimas delatan la afectación emocional de Juana, revelando la profunda tristeza que la embarga al revivir el suceso. Es importante resaltar que a dicha emoción le acompaña una gran culpa, por no haber permitido que el hijo llevara a su novia a vivir con él a la casa familiar. Tan grande era el remordimiento que acudió a confesarse, no con el padre de la iglesia de la subcomisaría, sino con una autoridad mayor, alguien con mayor influencia, más cercano a Dios o alejado de su comunidad. Para ello, se trasladó al centro de la ciudad de Mérida, para confesar su culpa al padre de la catedral. El padre la tranquilizó. Por un lado justificó su decisión de no permitir que el joven llevara a su novia a vivir con ellos, aunque por el otro, le dijo que Dios la iba a perdonar.

"Sí hija, tu quisiste su bien para él, pero él ya estaba cerrado su mente. Lo único que buscó es una salida muy fácil para él. Para él, matarse... ¡Ya estuvo! Pero lo que dejó a sufrir eres tú”, me dice, "y Dios... pues no, no está mal lo que tú hiciste. Le estabas abriendo su mente, pero él no quiso, está cerrada su mente, cerró su mente y Dios te va a perdonar hija”. Lo confesé llorando, lo confesé al padre.

EntreDiversidades. Revista de Ciencias Sociales y Humanidades, Vol. 9, Núm. 1 (18), enero-junio 2022. Páginas: 272-297 ISSN-e: 2007-7610. https://doi.org/10.31644/ED.V9.N1.2022.A11 
Y en efecto, mientras lo platicaba parecía revivir lo sucedido, lloraba con una profunda tristeza, quizá todavía un poco presa de la culpa. No obstante, pasado un rato, continúa su relato, en el que asigna toda la responsabilidad de lo sucedido a la novia del muchacho. Para dar más credibilidad a la acusación y no aparecer en primer plano pone como acusador al propio cadáver. Así, el muchacho señala a su verdugo por medio de uno de los recursos discursivos que aún le quedan: la sangre.

Fue esa muchacha [refiriéndose a la novia del muchacho], cuando estaba tendido él, así [con los brazos indica el largo y alto de la mesa donde habían colocado al cadáver], amaneciendo... así tendido... cuando vino esa Flor y esa sobrina y le quitaron el pañuelo que tenía yo puesto en su cara. Cuando le quitaron el pañuelo, jay, doctora, pero se le fue la sangre lejos, sobre de ellas casi! Solo porque se lo pusieron rápidamente. La sangre fue. Entonces, toda la gente que estaba acompañándome, le dijeron, ya habló él... por qué se mató, la sangre es lo que habla.

Juana hace referencia a la sangre como una forma de discurso del cadáver. En la comunidad de estudio se encontró que a las percepciones que tienen los dolientes sobre el suicida durante el velorio — visuales (sangre, lagrimeo, huellas dactilares — de otros — sobre su cuerpo), auditivas (llantos) o táctiles (flacidez o rigidez cadavérica) — se les da un significado y se procesan como una capacidad del difunto para expresarse y socializar, por última vez, a través de un lenguaje corporal. Esto lo he identificado como el último discurso del suicida (Hernández, 2014: 149-150). Por otra parte, Muchembled (2004 [2000]: 94) advierte que una vieja práctica de los jueces medievales en Europa consistía en observar el cadáver de una persona asesinada, pues esta sangraba en presencia de su agresor.

Ahora bien, el miedo se apodera de ella al terminar su explicación sobre la velación del difunto, así como lo ocurrido después del entierro. Sus gesticulaciones y el tono de voz denotan terror al describir al Demonio, quien rondaba la comunidad tras la muerte de su hijo. Con independencia de que lo haya visto, cosa que ningún otro poblador reporta, sabe, al igual que todos los demás, de lo que este Ser es capaz. Luego, el miedo surge por la posibilidad de que los eventos no deseados se repitan en la subcomisaría de no realizar los rituales de limpieza y exorcismo.

Agarré y vi... que dejo la puerta del solar, cuando yo vi hasta me confesé y me paré doctora, en la santa iglesia de los católicos que venían a dar testimonio... porque vi su cara, su cara, de la cara del mono, así delgada y así lleno de pelo negro, brilloso... pero era alto, más alto que la puerta, eso está chaparro a la puerta, el de mi casa estaba alto. Al rato, cuando mete su cabeza y empezó a venir de frente, pero cuando yo le dije a mi marido, vino mi marido, ya lo vi, se levantó mi marido corriendo para venir a verlo, salimos con velas y todo para verlo, y ipan!, se cerró la puerta.

Los vecinos, conocedores de los poderes del Mal, le dijeron a Juana que debía expulsarlo. Por tanto, recae en ella dicha responsabilidad, pues de no hacerlo, además de la amenaza de romper 
sus vínculos sociales, de por sí frágiles en la comunidad, corre el riesgo de cargar con la culpa de otros suicidios además del de su hijo, por no ahuyentar al Demonio de la subcomisaría. Desde luego, la atribución causal de la emoción hace que se propague entre la población, como si se tratase de un contagio.

"Lo tienes que sacar, porque ahí está arraigado", y yo le dije a dońa Carmen, ¿cómo le digo?, como yo nunca voy a la misa, no voy nunca a las oraciones, nunca salía yo, porque están chicos mis hijos y entonces yo le digo a doña Carmen: “¿Qué significa la oración que ustedes me dan para que yo haga y la oración que ustedes hacen?”. Y ella me dice: “Es que está arraigada, porque acá está, acá vive”.

Con los ojos fijos y más abiertos y un tono de voz más alto, Juana revive el miedo que experimentó entonces.

Por Diosito, por Nuestro Señor Jesucristo [invoca a Dios, para dar mayor credibilidad y reforzar su discurso], no te estoy mintiendo... pero me sacudieron mi hamaca. De todo me hizo, todo me hizo, oigo como [que] hablotean en la cocina, oigo que tiren mis cosas, oigo como [que] cierran la puerta del solar... ¡Dios mío! [vuelve a invocar a Dios, como lo hizo en aquel entonces] Digo entre mí, es eso, ese es el Mal, empecé a rezar la oración que me dieron ellos. Hay una oración que me dejaron, pues no vas a creer tantas oraciones, voy en la iglesia, oran por mi casa y vienen a mi casa a orar, cantan, rocían de agua bendita, no te voy a mentir doctora, con trabajo me dejó, con trabajo me dejó, pero era un Mal que de veras llegas a tenerle miedo, se me paraban [...] siento que se me paraban mis vellos, pero, siento que se me paraba mi pelo.

Llama la atención que, al ser presas del miedo, pueden temerle incluso a las que antes fueron sus mascotas, bajo la sospecha de estar poseídas por el Demonio. Luego, quizá como una regulación y control social, prefieren ahuyentarlas del lugar para evitar que suceda algo malo y los vecinos les responsabilicen del hecho. Por último, Juana termina su discurso recalcando la importancia de sacar al Mal de la población, antes de que "haga más barbaridades", para lo cual todos los parientes, vecinos y amigos del difunto deben unir esfuerzos y orar.

\section{Consideraciones finales}

En el artículo se analiza la cadena de emociones que surgen en las entrevistas a tres mujeres familiares de algún suicida. Primero, el discurso verbal de las entrevistadas revela ciertas emociones cargadas de significados, anclados en distintos contextos; mientras, el discurso no verbal contribuye a acentuar estas o desvelar otras tantas. A través de ambos se pueden identificar las atribuciones causales de las diferentes emociones, su afectación social, así como las funciones que emanan de cada condición emocional.

Sabemos que las emociones juegan un papel fundamental en el establecimiento del autocontrol y de los vínculos sociales y, como se mencionó al inicio, las interacciones sociales

EntreDiversidades. Revista de Ciencias Sociales y Humanidades, Vol. 9, Núm. 1 (18), enero-junio 2022. Páginas: 272-297 ISSN-e: 2007-7610. https://doi.org/10.31644/ED.V9.N1.2022.A11 
están atravesadas por ejes de poder y estatus. Así, a partir de la identificación de las emociones en el discurso de las entrevistadas pudimos observar la manera como se moldean los procesos de desigualdad y subordinación entre los actores de la subcomisaría y la forma como operan los sistemas de diferenciación en su vida cotidiana.

De este modo, en el caso de Alba, mientras ella sentía ira - acumulación emocional por la falta de compromiso del esposo para ir con ella al Centro, por haberla amenazado de muerte e irse al monte a colgar, además de las demandas, amenazas y humillaciones de los familiares políticos-, los presentes, entre los que se encontraban parientes del muchacho y vecinos, desaprobaban su malestar y emitían juicios condenatorios de manera profusa, induciéndole emociones de culpa y vergüenza, lo que estimaban más apropiado para el momento. La culpa al reprocharle su falta de responsabilidad para con su pareja, y la vergüenza cuando resucita en su discurso hechos pasados que socialmente le han señalado porque transgreden las normas sociales a las que deben ceñirse las mujeres en la comunidad — dicho sea de paso, normas muy distintas de las que rigen a los varones-. Lo anterior corresponde con dos de las reglas sociales de los sentimientos propuestas por Hochschild. Una de ellas es la dimensión normativa, esto es, lo que la persona siente que entra en conflicto con lo que la gente supone que debe sentir. La segunda es la dimensión política, en la cual las emociones sugeridas por aquellos que tienen más poder superan la emoción de Alba, cuyo capital es inferior en todos los sentidos (Hochschild, 1975: 288).

Los vínculos de las entrevistadas probaron ser muy frágiles. Alba, Martha y Juana estaban en una situación de vulnerabilidad e indefensión por el simple hecho de ser mujeres, lo que deriva en un capital social inferior al de casi cualquier varón. Con ello, sus oportunidades de lograr una regulación interpersonal se dificultaban. Más aún en el caso de Alba, por el grupo etario al que pertenecía. De ahí que, al final, termina exiliada en casa de los padres, sin poder recuperarse durante varios años. Así también, si se tratase de medir el capital social de estas tres mujeres, las de mayor edad tendría un mayor poder y estatus; en otras circunstancias la juventud puede representar un poder significativo, pero no fue así en el caso de Alba, a causa de los factores antes descritos. Por otro lado, vale seńalar que todas ellas carecían de un capital económico, social o simbólico que les proporcionara ciertas estrategias para el control de las diversas situaciones propiciadas por la gente.

A través de las entrevistas se pudo constatar cómo el poder y estatus de la concurrencia, al hacer gala de acciones coercitivas, amenazantes y represivas, propiciaron emociones negativas en las entrevistadas. En el caso de Alba, vergüenza y culpa; en el de Martha, vergüenza, culpa, frustración y animadversión hacia los vecinos que asistieron al sepelio; y en el caso de Juana, culpa, frustración por el desconocimiento de los hechos, resentimiento y desprecio hacia su familia política. No obstante lo anterior, al final, dichas emociones se dejan de lado y dan paso al miedo. Esto puede interpretarse como una regulación interpersonal positiva, a través de la cual se intentan recuperar y reconstruir las relaciones sociales, compartiendo la lucha para sacar al Mal de la comunidad. En ocasiones, esto se hizo a partir de estrategias de aceptación, huyendo de la situación, dejando al descubierto sus vínculos sociales inseguros, y en otras, mediante estrategias de posicionamiento, repartiendo parte de las culpas, con la intención de evitar acciones de mayor estigmatización o degradación.

EntreDiversidades. Revista de Ciencias Sociales y Humanidades, Vol. 9, Núm. 1 (18), enero-junio 2022. Páginas: 272-297 ISSN-e: 2007-7610. https://doi.org/10.31644/ED.V9.N1.2022.A11 
Así, en las entrevistas apareció una combinación indistinta de tres emociones básicas: ira, tristeza y miedo, que parecen entretejerse con las emociones de autoconciencia, vergüenza y culpa. Queda como interrogante si estas últimas dieron paso, de manera natural, al miedo, o si los actores sintientes convocaron esta emoción disposicional como una estrategia de regulación intra e interpersonal o como compensación para restablecer lo que podrían considerar como un equilibrio social.

Si se tratase de la segunda situación, podríamos inferir que las dolientes, al experimentar vergüenza y culpa por haber transgredido ciertos lineamientos sociales y verse descubiertas por otros actores, procuraron primero desvelar factores de culpa entre aquellos que estaban más cercanos o que identificaron como los más vulnerables de la concurrencia. Después, de manera consciente o inconsciente, cambiaron el foco de atención hacia una emoción básica, el miedo, una de las emociones más susceptibles de ser contagiadas (Rimé, 2012: 150-14). El contagio se hizo posible ya que un gran porcentaje de los pobladores le teme al Demonio o Mal. De esta forma, lograron que el total de la concurrencia desviara la mirada hacia su propia emoción y se ocupara de buscar protección para sí y su familia contra el contagio de una epidemia, el Diablo o algo desconocido.

Por último, hay que resaltar que se encontró cierto grado de autocontrol y automotivación en cada una de las entrevistadas por el hecho de seguir sus vidas día a día, a pesar de todos los obstáculos económicos y emocionales, entre otros, y por conservar cierto incentivo para convivir e incluso apoyar a otras personas. No obstante, queda pendiente para investigaciones posteriores, por un lado, la profundización en el análisis de la vergüenza, para poder determinar si en algunos de estos casos dicha emoción contribuye a inhibir o amplificar otras emociones como la ira. Por otro lado, cabría explorar el nivel de inteligencia intrapersonal de los actores sociales, ya que en ocasiones parece darse por sentado que todos gozan de un autoconocimiento total y objetivo de su forma de pensar, sentir y actuar; que poseen una consciencia plena de sus estados de ánimo, motivaciones, temperamentos y autoestima, entre otros factores. Lo anterior, debido a la importancia que deriva de un equilibrio emocional, pues este equilibrio evita situaciones estresantes, permite actuar con eficacia y redunda positiva e integralmente en el individuo.

\section{Bibliografía citada}

Ahmed, Sara (2015). La Política Cultural de las Emociones. 1a edición en español. México, D.F., México: Universidad Nacional Autónoma de México.

Armon-Jones, Claire (1985). "Prescription, Explication and the Social Construction of Emotion". Journal for the Theory of Social Behaviour, 15 (1), pp. 1-22. También disponible en: https:// doi.org/10.1111/j.1468-5914.1985.tb00042.x

Barbalet, Jack M. (1998). Emotion, Social Theory, and Social Structure: A Macrosociological Approach. Cambridge, United Kingdom: Cambridge University.

EntreDiversidades. Revista de Ciencias Sociales y Humanidades, Vol. 9, Núm. 1 (18), enero-junio 2022. Páginas: 272-297 ISSN-e: 2007-7610. https://doi.org/10.31644/ED.V9.N1.2022.A11 
Bericat Alastuey, Eduardo (2000). "La sociología de la emoción y la emoción en la sociología”. Papers, Vol. 62, pp. 145-176. También disponible en: https://papers.uab.cat/article/view/ v62-bericat

Bericat, Alastuey, Eduardo (2001). "El suicidio en Durkheim, o la modernidad de la triste figura”. Revista Internacional de Sociología, 59 (28), pp. 69-104. También disponible en: https:// doi.org/10.3989/ris.2001.i28.743

Bourdieu, Pierre (2013). "Capital simbólico y clases sociales". Herramienta. Revista de debate y crítica marxista [en línea], Núm. 52, pp. 1-11. Disponible en: https://www.herramienta. com.ar/articulo.php?id=1870 (Consultado el 12 de agosto de 2021).

Cuéllar Gutiérrez, Tania (2020). "El trabajo como vínculo socioafectivo: empleadoras y trabajadoras domésticas inmigrantes en la Ciudad de México”, en Ariza, Marina (coord.). Las emociones en la vida social: miradas sociológicas. Ciudad de México, México: Instituto de Investigaciones Sociales, Universidad Nacional Autónoma de México, pp. 255-292. También disponible en: https://www.iis.unam.mx/las-emociones-en-la-vida-socialmiradas-sociologicas/

Durkheim, Émile (2012 [1897]). El suicidio. Un estudio de sociología. 2a edición. Móstoles, Madrid, España: Editorial Akal.

Enciso Domínguez, Giazú y Lara, Alí (2014). "Emociones y ciencias sociales en el s. XX: la precuela del giro afectivo”. Athenea Digital [en línea], 14 (1), pp. 263-288. doi: http:// dx.doi.org/10.5565/rev/athenead/v14n1.1094 (Consultado el 27 de julio de 2021).

Elias, Norbert (2015 [1939]). El proceso de la civilización: investigaciones sociogenéticas y psicogenéticas. $4^{\mathrm{a}}$ edición. México, D.F., México: Fondo de Cultura Económica.

Fernández Poncela, Anna María (2011). "Antropología de las emociones y teoría de los sentimientos”. Versión. Estudios de comunicación y politica. Nueva Época [en línea], Núm. 26, pp. 1-24. Disponible en: https:/versionojs.xoc.uam.mx/index.php/version/ article/view/416 (Consultado el 27 de julio de 2021).

Flam, Helena (1990). "Emotional 'Man': II. Corporate Actors as Emotion-Motivated Emotion Managers". International Sociology [en línea], 5 (2), pp. 225-234. doi: https://doi. org/10.1177/026858090005002007 (Consultado el 27 de julio de 2021).

Fowler, William R. y Zavaleta Lemus, Eugenia (2013). "El pensamiento de Pierre Bourdieu: apuntes para una mirada arqueológica”. Revista de Museología Kóot [en línea], Año 3, Núm. 4, pp. 117-135. doi: https://doi.org/10.5377/koot.v0i4.2253 (Consultado el 27 de julio de 2021).

Garzón Guillén, Luis (2006). Trayectorias e integración de la inmigración argentina y ecuatoriana en Barcelona y Milano. Tesis para obtener el grado de Doctorado en Sociología, Facultat de Ciències Polítiques i de Sociologia, Universitat Autònoma de Barcelona. Disponible en: http://ddd.uab.cat/pub/tesis/2006/tdx-0216107-162125/lgg1de1.pdf (Consultado el 10 de agosto de 2021). 
Gutiérrez, Silvia, María Isabel Arbesú y Juan Manuel Piña (2014). "Emociones y representaciones sociales. El caso de los estímulos académicos”, en Mireles, Olivia (coord.). Representaciones sociales: emociones, significados y prácticas en la educación. México, D.F., México: Instituto de Investigaciones Sociales, Universidad Nacional Autónoma de México, pp. 19-50. También disponible en: http://www.iisue.unam.mx/publicaciones/libros/representaciones-socialesemociones-significados-y-practicas-en-la-educacion-superior

Gutiérrez Vidrio, Silvia y Reyna Ruiz, Margarita (2015). "El papel de las emociones en la incitación al consumo. Análisis de un programa radiofónico de corte religioso”. Comunicación y Sociedad [en línea], Año 12, Núm. 23, pp. 125-147. doi: https://doi.org/10.32870/cys. v0i23.66 (Consultado el 11 de mayo de 2021).

Hansberg, Olga E. (1996). "De las emociones morales”. Revista de Filosofía, 9 (16), pp. 151-170. Hernández Ruiz, Laura (2010). "Discurso en torno al suicidio en Chichí Suárez, Yucatán”. Anales de Antropología, Vol. 44, pp. 239-272. También disponible en: http://www.revistas.unam. mx/index.php/antropologia/article/view/25376

Hernández Ruiz, Laura (2014). Percepción y representaciones sociales del suicidio en Chichi Suárez, Yucatán. México, D.F., México: Centro Peninsular en Humanidades y Ciencias Sociales, Universidad Nacional Autónoma de México.

Hochschild, Arlie Russell (1975). "The Sociology of Feeling and Emotion: Selected Possibilities", en Millman, Marcia y Kanter, Rosabeth Moss (eds.). Another Voice: Feminist Perspectives on Social Life and Social Science. New York, United States of America: Anchor Books, pp. 280-307. También disponible en: https://doi.org/10.1111/j.1475-682X.1975. tb00339.x

Le Breton, David (2012). "Por una antropología de las emociones". Revista Latinoamericana de Estudios sobre Cuerpos, Emociones y Sociedad, Año 4, Núm. 10, pp. 67-77. También disponible en: http://www.relaces.com.ar/index.php/relaces/article/view/239

Lutz, Catherine A. (1988). Unnatural Emotions: Everyday Sentiments on a Micronesian Atoll and Their Challenge to Western Theory. Illinois, United States of America: University of Chicago Press.

Lutz, Catherine A. y Abu-Lughod, Lila (1990). "Introduction", en Lutz, Catherine A. (ed.). Language and the Politics of Emotion. Cambridge, United Kingdom: Cambridge University Press, pp. 1-23.

Macón, Cecilia (2014). "Género, afectos y política: Lauren Berlant y la irrupción de un dilema”. Debate Feminista, Vol. 49, pp. 163-186. También disponible en: https://debatefeminista. cieg.unam.mx/df ojs/index.php/debate feminista/article/view/1124/1001

Mancini, Fiorella (2016). "Emociones en riesgo. Miedo, vergüenza y culpa en tiempos de incertidumbre laboral”, en Ariza, Marina (coord.). Emociones, afectos y sociología. Diálogos desde la investigación social y la interdisciplina. México, D.F., México: Instituto de Investigaciones Sociales, Universidad Nacional Autónoma de México, pp. 193-240. También disponible en: http://ru.iis.sociales.unam.mx/bitstream/IIS/5233/4/emociones afectosc.pdf

EntreDiversidades. Revista de Ciencias Sociales y Humanidades, Vol. 9, Núm. 1 (18), enero-junio 2022. Páginas: 272-297 ISSN-e: 2007-7610. https://doi.org/10.31644/ED.V9.N1.2022.A11 
Muchembled, Robert (2004 [2000]). "El Diablo en el Cuerpo”, en Historia del Diablo Siglos XIIXX. México, D.F., México: Fondo de Cultura Económica, pp. 86-130.

Ortony, Andrew, Gerald L. Clore y Allan M. Collins (1988). The Cognitive Structure of Emotions. Cambridge, United Kingdom: Cambridge University Press.

Payá, Víctor Alejandro (2012). El don y la palabra. Un estudio socioantropológico de los mensajes póstumos del suicida. México, D.F., México: Juan Pablos Editor, Universidad Nacional Autónoma de México.

Plantin, Christian (2014). Las buenas razones de las emociones. Buenos Aires, Argentina: Universidad Nacional de Moreno. También disponible en: http://www.unmeditora.unm. edu.ar/index.php/colecciones/biblioteca-de-comunicacion/96-las-buenas-razones-de-lasemociones

Rimé, Bernard (2012). La compartición social de las emociones. 1a edición en español. Bilbao, País Vasco, España: Desclée de Brouwer.

Rodríguez Salazar, Tania (2008). "El valor de las emociones para el análisis cultural". Papers, Vol. 87, pp. 145-159. También disponible en: https://papers.uab.cat/article/view/v87rodriguez

Scheff, Thomas (1988). "Shame and Conformity: The Deference - Emotion System". American Sociological Review, 53 (3), pp. 395-406.

Turner, Jonathan (2007). Human emotions. A Sociological Theory. New York, United States of America: Routledge.

Villa Rojas, Alfonso (1995). "Dioses y espíritus paganos mayas", en Estudios Etnológicos. Los mayas. 2a edición. México, D.F., México: Instituto de Investigaciones Antropológicas, Universidad Nacional Autónoma de México, pp. 184-185. 